\title{
Effect of feeding fermented fish silage on the meat quality of broiler Japanese quails (Coturnix coturnix japonica)
}

\author{
SASMITA PANDA ${ }^{1}$, LAXMAN KUMAR BABU ${ }^{1}$, ARUN KUMAR PANDA², KULDEEP KUMAR \\ PANIGRAHY $^{3}$, SHAILESH KUMAR GUPTA ${ }^{3}$ AND PROMILA MARNDI ${ }^{4}$
}

\begin{abstract}
${ }^{1}$ Department of Livestock Production and Management, College of Veterinary Science and Animal Husbandry, Orissa University of Agriculture and Technology, BHUBANESWAR (ODISHA) INDIA

${ }^{2}$ ICAR- Central Institute for Women in Agriculture, BHUBANESWAR (ODISHA) INDIA

${ }^{3}$ Division of Livestock Production and Management, National Dairy Research Institute, KARNAL (HARYANA)

INDIA

${ }^{4}$ Department of Floriculture and Landscaping, College of Agriculture, Orissa University of Agriculture and Technology, BHUBANESWAR (ODISHA) INDIA

Email : smileysas555@gmail.com
\end{abstract}

Article Info : Received : 03.08.2016; Revised : 22.08.2016; Accepted : 09.09.2016

The research work was carried out for a total period of 4 weeks to study the effect of dietary supplementation of fermented fish silage on the meat quality of broiler Japanese quails. 192, seven-day old broiler Japanese quail chicks of either sex were randomly distributed into four dietary treatment groups with four replicates in each group with 12 chicks in each pen. The dietary treatments were $\mathrm{T}_{1}$ control diet, $\mathrm{T}_{2}$ diet containing 5 per cent fermented fish silage, $\mathrm{T}_{3}$ diet containing 10 per cent fermented fish silage and $\mathrm{T}_{4}$ diet containing 15 per cent fermented fish silage. The chemical composition like moisture, crude protein (CP) and ether extract (EE) content of the broiler quail meat taken from the breast region of birds did not vary significantly among the dietary treatments; however, there was a significant difference $(\mathrm{P}<0.05)$ in the total ash content. The total ash content in the meat samples of the birds fed diet containing 15 per cent fermented fish silage (FFS) was significantly higher $(1.94 \pm 0.06 \%)$ compared to all other dietary treatments. The inclusion of FFS had no adverse effect on meat composition (CP and EE). Further, FFS inclusion in the diet had a beneficial effect on meat ash content.

Key words : Fermented fish silage (FFS), Meat quality, Japanese quail

How to cite this paper : Panda, Sasmita, Babu, Laxman Kumar, Panda, Arun Kumar, Panigrahy, Kuldeep Kumar, Gupta, Shailesh Kumar and Marndi, Promila (2016). Effect of feeding fermented fish silage on the meat quality of broiler Japanese quails (Coturnix coturnix japonica). Asian J. Bio. Sci., 11 (2) : 277-280.DOI : 10.15740/HAS/AJBS/11.2/277-280. 